\title{
Persuasive Da'wah Agenda based on Sociodemographic Factors: A Study in Cimahi
}

\author{
${ }^{1}$ BAMBANG S.MA'ARIF, 2 UMAR YUSUF, ${ }^{3}$ SULIADI, ${ }^{4}$ PARIHAT \\ ${ }^{123}$ Universitas Islam Bandung, Jl. Tamansari no.1 Bandung, Indonesia \\ email: ${ }^{1}$ basmar_ali@yahoo.com; ${ }^{2}$ krumar@yahoo.com; ${ }^{3}$ suliadi@gmail.com; ${ }^{4}$ parihat@unisba.ac.id
}

\begin{abstract}
This paper is a result of primary research titled "Mapping the Profile of Persuasive Da'wah Agenda in Cimahi City." Cimahi is well known as the industrial centre of 'creative animation'. The method of research is quantitative by conducting surveys through questionnaires to 399 respondents in Cimahi using multistage random sampling technique. This paper presents important data on the socio-demographic factors of the citizens which can be basic in planning the effective $d a$ 'wah activities. The sociodemographic factor aforementioned are age, education, and gender of respondents. Those factors must be accurately identified in order to plan the persuasive $d a$ 'wah. The views of the citizens toward da'wah activity can be parameters toward persuasive da'wah, including what religious theme they preferred to, their preference on the actual da'wah themes, their liking on entrepreneurial $d a$ 'wah, etc. Citizens give responses to da'wah agenda of both bil-lisan (da'wah through speech) and bil-hal (da'wah through one's character). The more accepted a da'wah, it means the more persuasive the $d a$ 'wah is. When citizens do not like the da'wah, it can be said an unpersuasive one. Da'wah persuasion is closely related to its acceptability by the citizens.
\end{abstract}

Keywords: response to da'wah, mapping of da'wah activity, profile of persuasive da'wah,

\section{Introduction}

Cimahi is a comfortable independent city because of its relatively cool weather and its clear spring water. Many Cimahi residents work in Bandung City and its surroundings, and it resulted in an intensive interaction between the citizens. The population of Cimahi is more than 594,021 people (source: Statistical Bureau, BPS Cimahi, June 2016), which are spread over 3 districts, namely 163,452 people live in North Cimahi, 172,366 people in Central Cimahi, and 258, 203 people in South Cimahi. Their professions are labors, traders, private employees, farmers, businessmen/women, and civil servants.

Regarding da'wah (Islamic preaching), it needs to recognize the state of people they communicate with communicant, (Gullen, 2011: 213). The socio-demographic factor needs to be mapped accurately and is associated with the interest level of the da'wah. Cimahi has held many Islamic lectures, but at the same time, there are many law violations as well. These conditions gave rise to skepticism about the role of da'wah in the society.

People of Cimahi are religious, which can be indicated by the existence of many mosques and majlis taklim (a place where Muslim gather to learn Islam). Almost every sub-district holds weekly Islamic lectures by inviting an ustadz (a respected Islamic teacher), a typical da'wah activities with themes. Although the citizens are creative, consumptive, and fond of entertainment; nevertheless, Cimahi does not have night clubs, bars, nor discotheques.

The phenomenon is that da'wah asks the congregation to live moderate lifestyle (be thrifty, reasonable, and not wasteful). However, the city condition supports people to be creative, fashionable, and also consumptive. Consumerism inherent in big cities, including in Cimahi. The thing that must be considered is how to make the da'wah agenda is going to be favored by the citizen. 
This condition encourages the team researchers to conduct studies to determine to what extent people respond to da'wah, whether they like it and receive it well or not. Therefore, this paper took the title of "Persuasive Da'wah Agenda based on Sociodemographic Factors: Study in Cimahi". The demographic factor must be accurately studied to obtain the right data about the object.

A profile map of da'wah communication can be used by da'wah communicators to guide or plan the effective da'wah for the majlis/ congregation (al-jamaah), so that they will easily understand and implement the value of da'wah (Ma'arif, 2017: 277).

The absence of available data about Cimahi City residents' response to persuasive da'wah activities has caused da'wah activities depends on the mainstream of the da'i as a communicator. Research data can become a guideline for an effective da'wah regarding the figures of $\mathrm{da}^{\prime} \mathrm{i}$, themes, and medium in Cimahi. Da'wah activities are da'wah work program of both bil lisan and bil-hal.

Da'wah is an effort to invite people to live in the way of Allah and Islam religion. Da'wah is an effort to empower people through knowledge, attitude, and practice as a Muslim, so that they are able to be independent and develop (Ma'arif, 2010).

Religious teachings contain the main topics of the prime Islamic doctrine: aqidah (to be firm and tenacious), shari'a, and morals (Syaltut, 1966 and Anshary, 2001) with various derivatives. Amar ma'ruf and nahi munkar (ordering the right things and prohibiting the wrong ones) become the foundation of Islamic da'wah spirit. The main issue is how to implement Islamic teachings through da'wah in order to empower the community. Da'wah is an effort to invite people to the path of God as a straight path (Fadhlullah, 1997: 10). Life would be dark without da'wah because it enlightens Muslims. Da'wah is more than just a lecture or speech because it has an objective to invite the congregation to do good deeds and prohibit the wrong-doing (Pranggono, 2006: 12 and Abdurrahman 2010: 318). Da'wah is a macro structured framework, while amar ma'ruf is its spirit.

Da'wah has various forms. It is not only bil-lisan (verbally) but also bil-Hal (by actions) (Shihab, 2010). Bil-lisan is a verbal da'wah and Bilisan al-Hal (can be abbreviated as da'wah bil-Hal) is a da'wah that applying and implementing Islamic values aspects into real life. Bil-hal is not widely performed by Muslims. We do not intend to separate da'wah bil-lisan from da'wah bil-Hal. Otherwise, we need to differentiate these two types of da'wah.

The socio-demographic factors of the subjects who receive da'wah are age, gender, and education that need to be considered before giving a da'wah to. The condition of each community is different from the others. Based on socio-demographic point of view, we must take account those factors that make the citizens like the da'wah: the figure and its approach (da'wah bil-lisan and bil-hal (nonverbal and behavioral)).

In general, the agendas of da'wah are bil-lisan (verbal) and bil-hal (by action). Billisan is a verbal preaching such as lectures, recitals, discussions, seminar, and various forms of speech and writing. Meanwhile, da'wah bil-hal conveys the message of Islam in a practical and social charity to empower the community, such as training and apprenticeship to improve their understanding and skills in order to empower themselves.

There are a lot of entertainment businesses in big cities because people have money to enjoy these entertainments. Meanwhile, people in villages do not have much of modern entertainment. Their financial condition is also on average or below. That is why they need to be empowered. Empowerment process is conducted by the community (Suparta, 2003: xiv), including through da'wah.

In the concept of 'Pendidikan Berbasis Masyarakat' (Community Based Education)" (Suharto, 2012: 97), "Education is to conduct a critical reflection on the dominant ideology toward social transformation." The da'wah Bilhal is not far from the concept of communitybased education, which is conducted to manage their lives well and be independent.

Persuasive Da'wah was clearly expressed by The Prophet of Rasulullah SAW (PbuH). The prophet Muhammad SAW (PbuH) is a major figure in Islam. He introduced and spread Islam while facing many challenges without feeling tired. The prophet gave sirriyah (secret) da'wah for three years and continued with jahriyyah (open) da'wah. He received many rejections (Al-Mubarakfuri, 2001: 178). Prophet Muhammad is an example of a figure with persuasive da'wah due to his shiny personality and his character of someone who can highly be trusted (al-Amin). Prophet 
Muhammad SAW was the role model for ulama (Islamic scholars) in delivering a persuasive da'wah. A da'i must have 3 (three) main characters, namely knowledgeable, gentle, and patient (Taimiyah, 2001: 99). Da'wah becomes a persuasive bridge to reach one of its objectives, that is to change one's attitudes (Muhtadi, 2012: 46). When dakwah is favored -- because people agree with it -- it will give positive influence to the congregation.

Da'i does not force the congregation with their da'wah (coercive) because if they do that, they will lead to the imbalances of good deeds and hypocrisy. Da'wah should be performed persuasively in order to be effective because the congregation will understand and apply it in their life with their full awareness. Jowett and O'Donnell (2015: 37) defined persuasive as, "A communicative process to influence others. A persuasive message has a point of view or desired behavior for the recipient to adopt it in a voluntary fashion." While V. O'Donnell and June Kable (in Jowett and O'Donnell, 2015: 37) defined persuasive as "a complex, continuing, interactive process in which a sender and receiver are linked by symbols, verbal and nonverbal, through the persuader attempts to influence the persuade to adopt a change in a given attitude or behavior because the persuaded has had perceptions enlarged or changed."

Based on definitions from various literature, "persuasive" means an ongoing and complex process to influence others through messages, both verbal and nonverbal, which agreed to adopt a change in attitude and behavior voluntarily. The purpose of persuasive communication is for the communicants to willingly perform certain activities with full awareness (Effendi, 1989: 142). «Persuasive da'wah is the process of influencing mad'u (congregation) through a psychological approach and make them persuaded to do what a da'i said without the feeling of being forced. They feel they do it on their own will" (Mubarok, 2002: 161). Meanwhile, Shimp (2003: 118) stated that there are 4 basic factors in persuasion, two that controlled by communicators are message arguments and peripheral cues; while the other two are the involvement of receivers and initial positions.

There are four fundamental factors in persuasion process. Two factors (message arguments and peripheral cues) deal with persuasion tools under the communicator's control. The other two (receiver involvement and initial position) apply to characteristics of persuasion.

The study of attitudes is not solely centered on audiences or messages, but a combination of the two (Fletcher 1988: 21). Message content is also a persuasive communication element. Applbaum (1974: 88-110) stated that the strategy of designing persuasive communication is through message content. The contents of the message can be delivered in a way of the factual or provide proof, one side-two sides, scary-not scary persuasion, emotional-rationale, symbolicfactual, and humor.

Individual differences will lead to a different response or attitude towards an object. Communicators need to keep it in mind so that the deliverance of messages can change the audience's attitude according to the expected target, or at least to reduce energy exposure due to ineffectiveness of communication resulting from differences in audience response to messages. The concept of effective communication adapts to others who communicate; one's communication is effective as it adjusts the behavior, perception, and "device" to other communicator factors (Aubrey 1990: 434). Persuasion is based on a sense of responsibility because without accountability (Ma'arif, 2015: 162), the message of da'wah will be weak.

Da'wah can take place if there is a subject. The da'i (communicator of da'wah) serves to convey the messages of Islam. Da'wah is an art, a mission, and a perception" (Aripudin and Ruhiyat, 2015: 19). Furthermore, Arifin (2011: 265) stated, "Personality of the speaker is more important than the message conveyed." The da'is plays central figure in da'wah world. Rhetorist's personality has been attracted receivers' view in public spheres, such as Abdullah Gymnastiar and Jalaludin Rakhmat. Both are the prominent men in persuading public in da'wah context (Ma'arif, 2011: 39). Both deliver the inclusivity in da'wah sphere.

The theme of da'wah refers to the religious messages conveyed by da'i. Messages delivered are sourced from the Quran and Sunnah, including aqidah, sharia, and akhlaq (moral values). "Da'wah messages should educate people, not just give them a false hope" (Muhtadi, 2012: 41). When delivering a da'wah, things that have to be considered are the receivers, their age, and their intellectuals/ mindframe (Al-Faruq, 2013: 53). The themes of da'wah can lead to various applications of religious teachings in life. 
Da'wah does not merely deliver information, but also takes action; it is not only verbal but also real works/action. Therefore, the output is an effective and efficient da'wah (Abd. Rahman, 2009: 91) as the achievement of da'wah objective.

\section{Research Methodology}

This paper is an iteration of the result of research data processing through a survey in 2018. The questionnaires used Likert scale to find out citizens' response to persuasive da'wah agenda by considering their demographic factors. Cimahi divided into three areas: Cimahi Selatan (Southern Part), Cimahi Tengah (Central part), and Cimahi Utara (Northern Part). Unit of analysis is started from sub-district level down to lower subdivision, namely villages, RW (community unit), RT (neighborhood unit), and family unit. The researchers obtained data on the total population of Cimahi from Cimahi Statistical Bureau and distributed 465 questionnaires copies in all areas of Cimahi. 410 copies were returned back, and after the selection process, there are only 399 copies valid.

\section{Result And Discussion}

\section{Initial Data Description: Respondent's Characteristics}

Table 1 Age of Respondents

\begin{tabular}{ccc}
\hline Age & Frequency & Percent (\%) \\
\hline $\begin{array}{c}\text { Teenager } \\
(15-20)\end{array}$ & 82 & 20,55 \\
$\begin{array}{c}\text { Young Adult } \\
(21-40)\end{array}$ & 138 & 34,58 \\
$\begin{array}{c}\text { Middle Age } \\
(41-64)\end{array}$ & 134 & 33,58 \\
$\begin{array}{c}\text { Elderly } \\
(65-85) \\
\text { Total }\end{array}$ & 8 & 2.005 \\
\hline
\end{tabular}

Table 1 shows that $82(20.4 \%)$ respondents are teenagers between 15-20 years, 138 respondents $(34,58 \%)$ are young adult, 134 respondents $(33,58 \%)$ are middle age, and 8 respondents $(2,00 \%)$ are elderly.

The data informs that most of respondents are young adult and middle age more $78 \%$ (productive age) followed by teenagers whose aged 20 years and younger more than $20 \%$, and the least are elderly. The young adult and middle age can be categorized as a productive age. Their mobility and productivity are still long. Meanwhile, the elderly are only $2 \%$ of the citizens attend the da'wah activity.

\section{Age of Respondents}

In terms of age, more respondents of young adults and middle age expressed 'sympathy' or 'very sympathetic ' to a consistent da'i. Age does correlate to people liking the consistent Da'i.

Table 2

\section{Education of Respondents}

\begin{tabular}{lcc}
\hline \multicolumn{1}{c}{ Answer } & Frequency & $\begin{array}{c}\text { Percent } \\
(\%)\end{array}$ \\
\hline Elementary School & 15 & 3.8 \\
Junior High school & 109 & 27.3 \\
Senior High School & 176 & 44.1 \\
Associate Degree & 66 & 16.5 \\
Undergraduate & 23 & 5.8 \\
Do Not Answer & 10 & 2.5 \\
Total & 399 & 100.0 \\
\hline
\end{tabular}

Table 2 shows that the highest education level of respondents is senior high school of $176(44.1 \%)$ respondents. The second place is junior high school of 109 respondents $(27.3 \%)$; the third is associate degree graduates of $66(16.5 \%)$ respondents, followed by undergraduate of $23(5.8 \%)$ respondents, then elementary school graduated for $15(3.8 \%)$ respondents, and 10 (2.5\%) respondents did not answer.

These inform us that the respondents' educations are junior high school, senior high school, associate degree, and undergraduate. The average of citizens' education must be analyzed properly in order to manage the da'wah.

Table 3

Gender of Respondents

\begin{tabular}{lll}
\hline Answer & Frequency & Percent (\%) \\
\hline Male & 213 & 53.4 \\
Female & 186 & 46.6 \\
Total & 399 & 100.0 \\
\hline
\end{tabular}

Table 3 shows that a number of male respondents is $213(53.4 \%)$ and female is 186 respondents $(46.6 \%)$.

Most of the respondents of this research 
are male. Male pay more attention to the da'wah because they want to increase their knowledge and ability in practicing Islamic teaching. We know Islam is a comprehensive way of life. Islam can be elaborated by every Moslem in their daily life.

Table 4

Sympathy to the Consistent Da'i

\begin{tabular}{lcc}
\hline \multicolumn{1}{c}{ Answer } & Frequency & $\begin{array}{c}\text { Percent } \\
(\%)\end{array}$ \\
\hline Very Sympathetic & 107 & 26.8 \\
Sympathetic & 275 & 68.9 \\
Less sympathetic & 13 & 3.3 \\
Not sympathetic at all & 1 & 0.3 \\
Do not answer & 3 & 0.8 \\
Total & 399 & 100.0 \\
\hline
\end{tabular}

Table 4 shows that respondents in Cimahi are sympathetic to the consistent da'i (one word and deed) of 275 people $(68.9 \%)$, and very sympathetic of 107 (26.8\%). However, number of those who less sympathetic and not sympathetic at all are 14 respondents $(3.6 \%)$, while 3 people $(0.8 \%)$ do not answer.

Although the number is quite small, it should be observed of why some respondents are not sympathetic to the consistent da'i.

Table 5

The Preferred Religious Themes

\begin{tabular}{lc}
\hline \multicolumn{1}{c}{ Answer } & Frequency \\
\hline Worship & 153 \\
Aqidah & 128 \\
Moral & 101 \\
Mu'amalat & 58 \\
Marriage & 39 \\
Total & 479 \\
\hline
\end{tabular}

Table 5 shows the themes favored by Cimahi residents are worship chosen by 153 respondents (31.9\%), aqidah by 128 respondents (26.7\%), akhlaq chosen by 101 respondents (21.1\%), mu'amalat chosen by 58 respondents (12.1\%) chose, and marriage chosen by 39 respondents ( $8.1 \%)$.

The above data informs that the citizens of Cimahi need these themes. Sequentially, it is similar to the previous table. This means that religious themes that have been delivered are almost the same as what needed by citizens of Cimahi.
Table 6

Preference of The Actual Da'wah Themes

\begin{tabular}{lcc}
\hline \multicolumn{1}{c}{ Answer } & Frequency & $\begin{array}{c}\text { Percent } \\
(\%)\end{array}$ \\
\hline Like it very much & 73 & 18.3 \\
Like it & 314 & 78.7 \\
Do not really like it & 9 & 2.3 \\
Do not like it at all & 2 & 0.5 \\
Do not answer & 1 & 0.3 \\
Total & 399 & 100.0 \\
\hline
\end{tabular}

We know that a lot of respondents like and very like the actual da'wah themes. Thus, the da'i ought to deliver the actual themes of da'wah, or they can contextualize the theme with the actual things. The contextualization of da'wah will influence the public's perception of the level that they can understand the meaning of Islamic teaching in a social context. Da'i must elaborate the Islamic teaching with the actual reality or events they observe from reality.

Table 7

Rate of Liking for the Entrepreneurial Da'wah

\begin{tabular}{lcc}
\hline \multicolumn{1}{c}{ Answer } & Frequency & Percent (\%) \\
\hline Like it very much & 69 & 17.3 \\
Like it & 291 & 72.9 \\
Do not like it & 32 & 8.0 \\
Do not like it at all & 2 & 0.5 \\
Do not answer & 5 & 1.3 \\
Total & 399 & 100.0 \\
\hline
\end{tabular}

Table 7 shows that 291 (72.9\%) respondents like dakwah bil-Hal, 69 respondents $(17.3 \%)$ like it very much, 32 respondents $(8 \%)$ do not like it, t2 respondents $(0.5 \%)$ do not like it at all, and 5 respondents $(1.3 \%)$ do not answer.

\section{Socio Demographic Factors as A Controller}

\section{Age and Preferred Religious Themes}

Tabel 8 shows Correlation between Preferred Religious Themes and Age that most of respondents preferred aqidah (theology) and worship themes. Teenager preferred theology, worship, and marriage themes. While elderly, preferred aqidah and worship. 
Table 8

Correlation between Preferred Religious Themes and Age

\begin{tabular}{|c|c|c|c|c|c|c|c|c|}
\hline \multirow{2}{*}{\multicolumn{2}{|c|}{$\begin{array}{l}\text { Aqidah } \\
\text { (theology) }\end{array}$}} & \multirow{3}{*}{$\frac{\text { Worship }}{20}$} & \multicolumn{4}{|c|}{ The Preferred Religious Themes } & & \multirow[b]{2}{*}{ Total } \\
\hline & & & Mu'amalat & Marriage & Moral & $\begin{array}{c}\text { No } \\
\text { Answer }\end{array}$ & & \\
\hline \multirow[t]{4}{*}{ Age } & $\begin{array}{l}\text { Teenager } \\
(15-20)\end{array}$ & & 19 & 8 & 19 & 16 & 0 & 82 \\
\hline & $\begin{array}{l}\text { Young Adult } \\
(21-40)\end{array}$ & 59 & 37 & 10 & 3 & 29 & 0 & 138 \\
\hline & $\begin{array}{l}\text { Middle Age } \\
(41-64)\end{array}$ & 50 & 46 & 13 & 2 & 22 & 1 & 134 \\
\hline & $\begin{array}{l}\text { Elderly } \\
(65-85)\end{array}$ & 20 & 13 & 2 & 1 & 8 & 1 & 45 \\
\hline \multicolumn{2}{|c|}{ Total } & 149 & 115 & 33 & 25 & 75 & 2 & 399 \\
\hline
\end{tabular}

Based on that, there is a correlation of the preferred da'wah themes with age. We understand that the preferred themes are the message in da'wah activity. When we really prefer the message, it will become a tool of persuasion.

Table 9 shows a Correlation between Income and the Method of Da'wah Bil-Hal As an Empowering Tool that income correlates to the perception of society, especially in da'wah. Cimahi Citizens have income and there are also those who do not have income. Income has a correlation with the technic of da'wah. Citizens of Cimahi percept that da'wah bil-Hal is important for them because it will empower society. It shows us that there is correlation between income and the preference of da'wah bil-Hal. The less income of citizens, the stronger the preference.

Da'i should consider da'wah bil-Hal and must conduct it. Da'wah that must be delivered is da'wah bil-Hal. Dai also ought to convey the entrepreneurial da'wah, due to the emerging problems faced by society. When a society has no income, they will appreciate da'i who deliver da'wah bil-Hal to empower the marginal community, and citizens will like it.

\section{Education}

Table 10 shows the Correlation between Education and Sympathy to the Consistent $\mathrm{Da}^{\prime} \mathrm{i}$ that most of the respondents who expressed "sympathetic" and "very sympathetic" to the consistent da'i are from junior and senior high school graduates followed by Associate degree and Undergraduate. Associate degree and undergraduate are also sympathetic and very sympathetic to consistent da'i.

This informs us that there are no differences of education factor to the preference of consistent da'i. All level of citizens' education gives good appreciation

Table 9

Correlation between Income and the Method of Da'wah Bil-Hal As an Empowering Tool

\begin{tabular}{|c|c|c|c|c|c|c|}
\hline & \multirow{2}{*}{ Yes } & \multicolumn{4}{|c|}{ Capability of Da'wah Bil-Hal to Empower the Society } & \multirow{2}{*}{ Total } \\
\hline & & No & Occasionally & No Answer & & \\
\hline \multirow{4}{*}{$\begin{array}{l}\text { Level of } \\
\text { Income }\end{array}$} & No Income & 124 & 13 & 4 & 3 & 144 \\
\hline & $\begin{array}{l}500.000- \\
2.000 .000\end{array}$ & 140 & 7 & 0 & 3 & 150 \\
\hline & $\begin{array}{l}2.000 .001- \\
6.000 .000\end{array}$ & 93 & 3 & 3 & 2 & 101 \\
\hline & $\begin{array}{l}\text { More than } \\
6.000 .0001\end{array}$ & 2 & 2 & 0 & 0 & 4 \\
\hline Total & & 359 & 25 & 7 & 8 & 399 \\
\hline
\end{tabular}


MIMBAR, Vol. 35 No. $1^{\text {st }}(2019)$

Table 10

Correlation between Education and Sympathy to The Consistent Da'i

\begin{tabular}{|c|c|c|c|c|c|c|c|}
\hline \multirow{2}{*}{\multicolumn{2}{|c|}{ Very Sympathetic }} & \multicolumn{4}{|c|}{ Sympaty to the Consistent $\mathrm{Da}^{\prime} \mathrm{i}$} & & \multirow[b]{2}{*}{ Total } \\
\hline & & \multirow{2}{*}{$\begin{array}{c}\text { Sympathetic } \\
5\end{array}$} & \multirow{2}{*}{$\begin{array}{c}\text { Less } \\
\text { Sympathetic } \\
9\end{array}$} & \multirow{2}{*}{$\begin{array}{c}\text { Not } \\
\begin{array}{c}\text { Sympathetic } \\
\text { at all }\end{array} \\
1\end{array}$} & \multirow{2}{*}{$\begin{array}{c}\text { Do Not } \\
\text { Answer }\end{array}$} & & \\
\hline \multirow{6}{*}{ Education } & $\begin{array}{l}\text { Elementary } \\
\text { school }\end{array}$ & & & & & 0 & 15 \\
\hline & $\begin{array}{l}\text { Junior High } \\
\text { school }\end{array}$ & 32 & 71 & 6 & 0 & 0 & 109 \\
\hline & $\begin{array}{l}\text { Senior High } \\
\text { school }\end{array}$ & 36 & 133 & 5 & 1 & 1 & 176 \\
\hline & $\begin{array}{l}\text { Associate } \\
\text { Degree }\end{array}$ & 27 & 39 & 0 & 0 & 0 & 66 \\
\hline & Undergraduate & 6 & 16 & 0 & 0 & 1 & 23 \\
\hline & Do not answer & 1 & 7 & 1 & 0 & 1 & 10 \\
\hline \multicolumn{2}{|l|}{ Total } & 107 & 275 & 13 & 1 & 3 & 399 \\
\hline
\end{tabular}

to the consistent da'i. It is better to say that the consistent $d a^{\prime} i$ is a must for citizen of all level of education.

\section{Discussion and Analysis}

The data shows there are 3 (three) elements of persuasive da'wah: preference of religious themes, preference of entrepreneurship da'wah, and sympathy or the consistent da'i. These elements correlate with sociodemographic factors.

The purpose of persuasive communication is to make the communicants willingly perform certain activities in full awareness. Persuasive da'wah is the process of influencing mad'u (congregation) with a psychological approach, and therefore mad'u is persuaded to do what a da'i said without the feeling of being forced. They feel that they do it on their own will.

The personality of $\mathrm{Da}^{\prime} \mathrm{i}$ is more important than the themes of his da'wah, approach, and media. Sociological reality is found in real life as well as in this study, where a consistent da'i receives 'sympathetic' and 'very sympathetic' valuation from respondents.

Without the presence of $\mathrm{da}^{\prime} \mathrm{i}, \mathrm{da}$ 'wah will not being performed and there will be no achievements. There is correlation between socio-demographic factors and the people's preference to a da'wah agenda. thus, we have to pay attention to the figure, message, and the method of da'wah in an attempt to persuade the public.
Shimp's statement explains there are 4 basic factors in persuasion. Two are controlled by communicators, namely, message arguments and peripheral cues; the other two are the involvement of receivers and initial positions. The researcher limits the major sociodemographic factors to be discussed into three elements: age, income, and education associated with the people's preference of da'i communicators, with the consideration that the figure of $d a ' i$ is the gateway for the realization of da'wah.

Da'wah becomes a persuasive bridge to one of its objectives, which is to change one's attitudes. When da'wah is favored --because people agree with it-- it will give positive influence to the congregation.

A persuasive da'wah becomes reality when it is liked and appreciated by the people. Factors that play an important role in persuasive da'wah are $\mathrm{da}^{\prime} \mathrm{i} / \mathrm{communicator}$ (his characters, language, and description), themes, techniques, and the media. A da'i must have good moral characters, especially consistency. It means a da'i has an obligation to apply his own teaching to himself. The da'i's attitude and behavior must reflect in his daily life. Without $d a$ 'i's consistency, their preaching will be denied by the public. Instead of passive, public of da'wah are actively valued his figure. Then, the figure of da'wah is not merely speaking in front of his public, but also has to apply what he is preaching. The preaching of Islam nowadays needs to be developed.

Da'wah should be performed 
persuasively in order to be effective because the congregation understand and will apply it in their life with full awareness. Persuasive is an ongoing and complex process to influence others through messages, both verbal and non-verbal, which agreed to adopt a change in attitude and behavior voluntarily.

\section{Analysis}

The researcher uses a persuasive concept that is implemented in the world of da'wah supported by the theory of community empowerment. Da'wah should connect the factor of da'wah subject $\left(D a^{\prime} i\right)$ with da'wah receiver in one format to study the data of this research. The factor of socio-demographic gives community a preference of da'wah aspects which include the $D a$ 'i figure, da'wah messages, and da'wah media.

The da'i who sends the message of da'wah to the receivers becomes the key to the persuasion of da'wah. The persuasion of da'wah is based on a credible da'i and suitable messages wished by the community. Da'wah must give an understanding of the teachings of Islam and its practice in our daily lives including problem-solving for humanity and nationality. Based on the result of this research, people have the expectation that da'wah bil-hal is developed because it will empower the community.

In contrast to general information deliverance, da'wah activities require exemplary figures and messages that inspire people's feelings. Whereas, mass media and social media are mostly used by people to access general information. People like da'wah billisan and bil-Hal activities. They perceive da'wah bil-lisan delivers knowledge, shapes people's attitudes, and helps people to apply the knowledge in their daily life; da'wah bil-Hal improves community self-reliance; it has the potential to answer the challenges of life of the people. Most people need a balance between da'wah bil-hal and da'wah bil-lisan, therefore, it can create a persuasive da'wah.

Religious teachings contain the main topics of the prime Islamic doctrine: aqidah (to be firm and tenacious), shari'a, and morals with various derivatives. Amar ma'ruf and nahyi munkar (ordering the right things and prohibiting the wrong) becomes the foundation of Islamic spirit. The main issue is how to implement Islamic teachings in daily life to empower the community.

The agenda of dakwah are bil-lisan (verbal) and bil-hal (by action). Bil-lisan is a verbal preaching such as lectures, discussions, seminar, and various forms of speech and writing. Meanwhile bil-hal conveys the message of Islam in a practical and social charity to empower the community, such as training and apprenticeship to improve their understanding and skills. It is an effort to invite people to live in the way of Allah and Islamic religion.

Da'wah is an effort to empower people through knowledge, attitude, and practice as a Muslim, so that they are able to be independent and develop. We have to pay attention to the sociodemographic factors as predictive elements to persuasive dakwah. Whenever da'wah appreciated by the public, they will appreciate the da'i. The more accepted the da'wah, the more persuasive it will be.

\section{Conclusions}

The citizens of Cimahi have sociodemographic factors to be considered in preparing a da'wah activity. The profile of da'wah figures favored by the people, especially a consistent figure. The Favorable themes of da'wah are aqidah, worship, and morality, which is combined with actual examples; and da'wah bil-Hal is favored because it can empower the society. A da'wah is persuasive when the figure of da'wah is a consistent personality widely accepted by the public and plays a strategic role in giving da'wah agenda persuasively. He is able to select which themes will be delivered to the public. The community expects a da'wah bil$\mathrm{Hal}$, which has added value and are needed to be self-reliance. The objectives of da'wah bil-lisan are to improve knowledge, build characters and attitude, and improve the implementation of Islamic values. Meanwhile, da'wah bil-hal is to develop self-ability in practical matters and entrepreneurship.

Further research related to the da'wah agenda through the central path is needed in order to have a stronger persuasion. People expect the agenda of da'wah bil-Hal to be larger. Further research is needed to create a memorable and stronger da'wah; the usefulness and community self-reliance; da'wah helps people to be self-reliant and progressive.

\section{References}

Abdurrahman. (2010). Recik-Recik Dakwah. 
Bandung: Sinar Baru Algesindo.

Abd. Rahman, D. (2009). Kisi-Kisi Materi Bekal Dakwah. Bandung: Mujahid.

Al-Mubarakfuri, S. (2001). Perjalanan Hidup Rasul Yang Agung Muhammad Saw. dari Kelahiran Hingga Detik-Detik Terakhir. Jakarta: CV. Mulia Sarana Press.

Al-Faruq, M. (2013). Konsepsi Dakwah. Jakarta: Pustaka Firdaus.

Anshary, E. S. (2001). Wawasan Islam. Jakarta: Erlangga.

Applbaum, Ronald L., dan Anatol, Karl W., (1974). Strategic for Persuasive Communication. Columbia, Ohio: Charles E. Merrill Publishing Company.

Arifin, A. (2011). Dakwah Kontemporer Sebuah Studi Komunikasi. Yogyakarta: Graha IImu.

Aripudin, A., and Ruhiyat. (2015). Pengembangan Materi Dakwah. Bandung: CV Mimbar Pustaka.

Aubrey, (1990). Dimensi-Dimensi Komunikasi. Bandung: Rosda Karya.

Effendi, O. U, (1989). Kamus Komunikasi. Bandung: Mandar Maju.

Fadhlullah. (1997). Konsep Dakwah. Bandung: Nuansa.

Fletcher, G.J.O., Finham, F.D., Cramer, L., \& Heron, N. (1988). The Role of Attributions in the Development of Dating Relationships. Journal of Personality and Social Psychology, 53, 481-489.

Gullen, F. (2011). Dakwah Jalan Terbaik dalam Berpikir dan Menyikapi Hidup. Jakarta: PT. Gramedia.

Jowett, G. S., O'Donnel, V. (2015). Propaganda and Persuasion, sixth edition. Los Angeles: Sage Publication.

Ma'arif, B., S. (2010). Komunikasi Dakwah Paradigma untuk Aksi. Bandung: Simbiosa Rekatama Media.
Ma'arif, B., S. (2011). Dimensi Inklusif Dakwah KH. Abdullah Gymnastiar dan $\mathrm{KH}$. Jalaluddin Rakhmat. MIMBAR Jurnal Sosial dan Pembangunan, vol. XXVII, No. 1 [June], p. 39-46.

Ma'arif, B., S. (2015). Psikologi Komunikasi Dakwah Suatu Pengantar. Bandung: Simbiosa Rekatama Media.

Ma'arif, B., S. (2017). Mapping of Dakwah Activity in Bandung City. MIMBAR Jurnal Sosial dan Pembangunan, vol. XXXIII, no. 2 [December], p. 219-472.

Mubarok, A.(2002). Psikologi Dakwah. Jakarta: Pustaka Firdaus.

Muhtadi, A. S. (2012). Komunikasi Dakwah Teori, Pendekatan, dan Aplikasi. Bandung: Simbiosa Rekatama Media.

Pranggono, B. (2006). Mozaik Dakwah Kumpulan Tulisan 1966 - 2006. Bandung: Khazanah Intelektual.

Shihab, Q. (2010). Membumikan Al-Quran. Bandung: Mizan.

Shimp, T. A. (2003). Advertising, Promotion, And Supplemental Aspects of Integrated Marketing Communication. sixth edition. Australia: Thompson.

Suharto, T. (2012). Pendidikan Berbasis Masyarakat Relasi Negaradan Masyarakat dalam Pendidikan. Yogyakarta: LKiS.

Suparta, M, (editor). (2003). Metode Dakwah. Jakarta: Prenada Media.

Statistical Bureau/Badan Pusat Statistik (BPS). Cimahi Dalam Angka.Cimahi, June 2016. (https://cimahikota. bps.go.id/publication/2016/07/15/ b647e19b84f3a824f4f67771/kota-cimahidalam-angka-2016.html)

Syaltut, M. (1966). Al-Islam Aqidah wa Syari'ah. Beirut: Dar al-qolam.

Taimiyah, I. (2001). Manhaj Dakwah Salafiyah. Jakarta: Pustaka Azzam. 